\title{
Productivity and Profitability of Abaca Varieties/Hybrids (Musa textiles Nee) Under Mature Tall Coconuts in Davao City, Southern Mindanao, Philippines
}

\author{
M.I. Secretaria ${ }^{1}$, M.N. Eroy $^{2}$ and O.B. Macarayan $^{3}$
}

\begin{abstract}
Two abaca varieties; Tangongon and Maguindanao, and two hybrids; Magino and Bongtang were grown under mature Laguna Tall coconuts spaced 9x9 m triangular in Bago Oshiro, Davao City from 2006-2010. The growth, yield and economic performance of these varieties/hybrids were evaluated to identify varieties/hybrids suitable as coconut intercrop and to show its suitability as coconut+abaca intercropping.

Magino, a cross between Maguindanao and Inosa, was the consistent highest yielder. It had good yield attributes like good suckering ability, taller and bigger plants contributing to high fiber yields and high economic returns i.e. NPV and BCR. Maguindanao variety and Bongtang hybrid had comparable performance with Magino hybrid. Tangongon variety is the consistent lowest yielder with yield and yield attributes inferior to the rest of the plants tested affecting its profitability.

Crop Fertilizer Use Efficiency (CFE) using fiber yield as an index revealed that top yielding entries are more efficient in converting fertilizer inputs into economic yield as reflected by their high CFEs.

Abaca is a highly suitable intercrop for coconut and coconut areas could be used as expansion areas for growing the crop. Profitability of abaca farming under coconut is influenced by the variety used. Some drawbacks in abaca farming and good practices are discussed.
\end{abstract}

Keywords: abaca, coconut intercropping, yield performance, profitability

\footnotetext{
${ }^{1}$ Former Scientist I/SRS II, PCA-Davao Research Center, Bago Oshiro, Davao City, Philippines.

${ }^{2}$ SRS II, PCA-Davao Research Center, Bago Oshiro, Davao City, Philippines. Email: eroymarianita@yahoo.com (corresponding author)

${ }^{3}$ Director II, FIDA, Region XI, Davao City, Philippines.
} 


\section{Introduction}

Abaca (Musa textilis Nee), known worldwide as Manila hemp, is indigenous to the Philippines and thrives well in some parts of the country because of the favourable agroclimatic conditions particularly the rich volcanic soil and tropical weather. Its product, abaca fiber, became well known as one of the strongest materials for marine cordage because of its superior tensile strength and proven durability under water and with the onset of the $20^{\text {th }}$ century, it has become the premier export commodity of the Philippines (FIDA, 2012).

The Philippines contributes $84 \%$ of the total world abaca fiber production, a dominant lead in the global abaca market with Ecuador supplying the rest. Such market dominance has made abaca one of the country's top dollar earners. Within the last decade, it contributed an average of US\$76.8 million annually in export earnings from its products namely: fiber, pulp, cordage, yarns and fabrics and fiber craft (Lalusin, 2010).

It provides livelihood security to abaca farmers and manufacturers and generates employment in the abaca manufacturing industry. The abaca industry supports the livelihood of around 140,000 abaca farm workers and strippers, as well as 78,000 small farmers with approximately more than 430,000 dependents and 143,429 strippers. The fiber craft industry, which produces bags, rugs, placemats, hats, hot pads, coasters, yarns, and hand-woven fabrics, provides livelihood to rural women and out-of-school youths."

The several typhoons and pest and diseases that adversely affected abaca production in the traditional growing areas led to the opening of new abaca farms in less prone to typhoon and disease-free areas particularly in Mindanao starting in the mid 2000. The unutilized spaces in coconut farms are potential areas for abaca expansion. The climatic requirements of both crops are quite similar making them a compatible combination. Abaca being shade tolerant makes it a good under storey crop. Although intercropping is widely practiced in coconut farms, very few are into abaca intercropping which are mostly concentrated in Visayas. Research on abaca under coconut in Mindanao is nil. In the Visayas, earlier reports (Tafalla,1991) revealed a strong influence of varieties on the performance of the crop under coconut thus identification of varieties adopted under this condition is very important to refine recommendation for farmer's adoption.

Given the potential of coconut farms as expansion areas and the huge areas available for intercropping specifically in Southern Mindanao, this techno demo cum abaca varietal trial under mature Laguna Tall (LAGT) coconuts under Davao condition was conducted in collaboration with Fiber Industry Development Authority (FIDA)-Region XI. This collaboration aimed to determine the performance of four varieties/hybrids of abaca under coconut, to evaluate the economics of abaca farming under coconut and to demonstrate the feasibility of abaca intercropping under bearing tall palms at the Philippine Coconut Authority-Davao Research Center (PCA-DRC).

\section{Materials and Methods}

The techno-demo cum abaca varietal trial under coconut was conducted from October 2006 to December 2010 at the experimental area of PCA-Davao Research Center, Davao City, Philippines. The station is located in a highly suitable growing zone with Type 1 rainfall (at most 3 dry months with uniform rainfall distribution). Its soil is mainly of the Tugbok clay loam (Typic tropudalfs) deep and welldrained.

Two to three month old seed pieces of four abaca varieties/hybrids namely, 1) Tangongon 2) Maguindanao 3) Bongtang (Bongolanon $\mathrm{x}$ Tangongon) and 4) Magino (Maguindanao $x$ Inosa) were planted under 32 year old Laguna Tall (LAGT) coconuts spaced 9x9m triangular. Abaca seedlings were planted at a distance of $2.5 \times 2.5 \mathrm{~m}$ square method in between rows of coconut to give an effective planting density of 1,071 plants/ha in October 2006. Each elementary plot consisted of 9 coconut palms occupying an area of and 30 abaca seedlings of each variety/hybrid and replicated four times. 
Prior to the start of the study, the coconuts were under two pruning conditions: with and without leaf pruning at leaf rank no. 23 but succeeding pruning was discontinued because of the observed damaged caused by falling cut leaves on the young abaca plants.

At planting, basal application of 660 $\mathrm{g} /$ plant of cocopeat-based organic fertilizer with an average nutrient content of $2.2 \% \mathrm{~N}, 3.24 \% \mathrm{P}$ and $0.45 \% \mathrm{~K}$ followed by $300 \mathrm{~g} / \mathrm{plant}$ ammonium sulfate $(21 \% \mathrm{~N}$ and $24 \% \mathrm{~S})$ were done. Complete fertilizer (14-14-14 NPK) at the rate of $250 \mathrm{~g}$ /clump was applied 14 months after planting and every year thereafter. Being under coconut, no additional shade was provided for the newly-planted crop. The crops were kept weed-free by ringweeding and slashing or sometimes with the use of broad spectrum herbicide. Undesirable suckers were likewise removed from time to time. Presence of pest and disease were monitored regularly and affected plants were removed and disposed properly. Other recommended cultural practices were followed.

Harvesting of abaca for fiber production started at 24 months after planting, October 2008, and yearly thereafter. The processing of the abaca was done by strippers using a spindle stripping machine provided by FIDA following recommended practices (FIDA, 2005).

Data collected were on the number of suckers at one year after planting and during harvesting, the number of harvested plants, length and weight of logs or harvested plant, weight of tuxy and fiber yield were collected. Data were statistically analyzed and treatment means were compared using DMRT. The efficiency of the varieties in utilizing inputs like fertilizer was assessed using the crop fertilizer use efficiency (CFE) with fiber as the index. This was measured by the amount of dry fiber obtained per unit of fertilizer applied.

\section{Results and Discussion}

\section{A. Performance of abaca under coconut}

At one year after planting, the suckering ability of the different varieties significantly differed (Table 1). Among the varieties, Magino hybrid produced the highest number of suckers at 5.3 suckers/clump. Tangongon produced the least at 2.6 suckers/clump. Mangino significantly outnumbered Maguindanao variety and Bongtang hybrid which produced 3.4 and 3.7 suckers respectively.

\section{Figure 1a) Abaca planted under coconut and 1b) fiber processing using a mechanical stripper (PCA-DRC)}

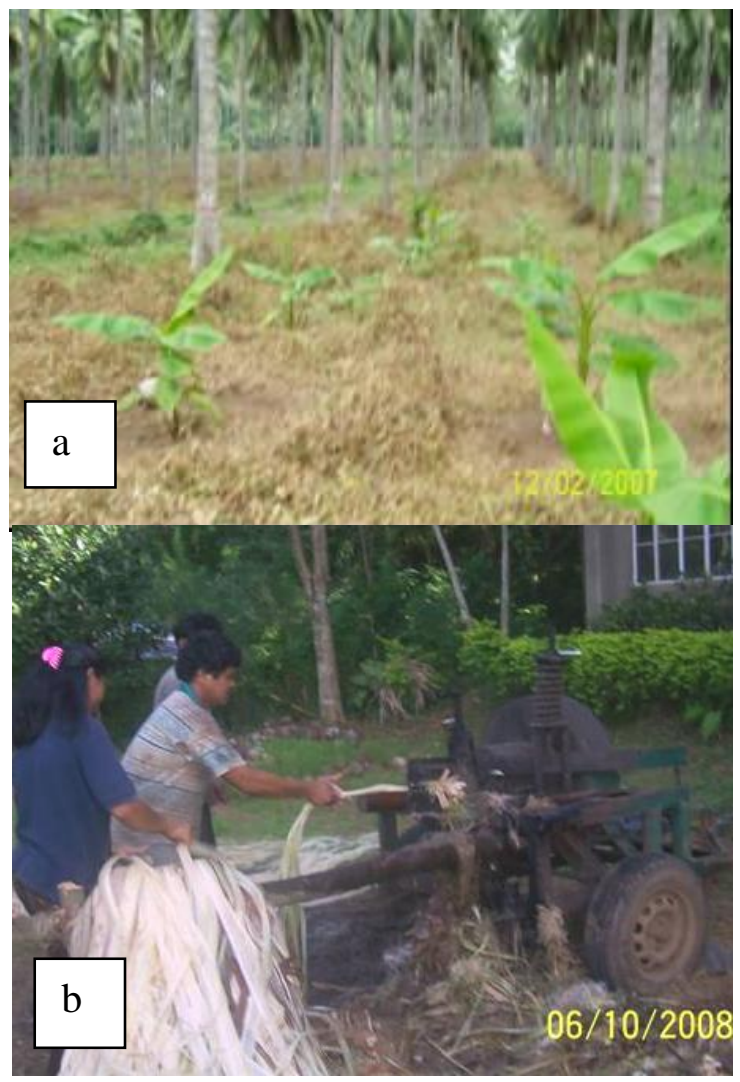

Table 1. Number of suckers produced per plant by four abaca varieties/ hybrids planted under mature LAGT palms (PCA-DRC, 2007)

\begin{tabular}{|l|c|}
\hline \multicolumn{1}{|c|}{ Entries/Varieties } & $\begin{array}{c}\text { No. of suckers/ } \\
\text { clump }\end{array}$ \\
\hline T1 - Tangongon variety & $2.6 \mathrm{c}$ \\
T2 - Maguindanao variety & $3.7 \mathrm{~b}$ \\
T3 - Bongtang hybrid & $3.4 \mathrm{~b}$ \\
T4 - Magino Hybrid & $5.3 \mathrm{a}$ \\
\hline Stat. significance & $* *$ \\
C.V. $(\%)$ & 12.7 \\
\hline
\end{tabular}


Initial harvesting for abaca fiber production was done at exactly two years after field planting. The length and weight of the harvested stalks of the different varieties were not significantly different (Table 2). The length ranged from $2.77 \mathrm{~m}$ to $2.99 \mathrm{~m}$ while the weight ranged from $18.8 \mathrm{~kg}$ to $22.9 \mathrm{~kg}$. Comparable number of mature or harvestable plants was noted in the three varieties: Bongtang and Magino hybrids and Maguindanao variety ranging from 4.0-5.2 plants/clump. The least was obtained with Tangongon variety with 2.4 plants/clump. In terms of dry fiber yield per plant, there were no significant differences among the varieties with yield ranging from 390$505 \mathrm{~g} /$ plant. The low number of harvestable plants of the Tangongon variety was compensated by its higher fiber recovery of about $2.5 \%$ thus a high fiber yield per plant. Based on computed fiber yield per ha, no significant differences were noted among the four varieties although Bongtang produced the highest of 1.0 ton/ha.

Although there was no separate grading of the fiber from each variety, it was noted that during the bulk sales of the fiber, $88.3 \%$ was classified excellent (S2-76\% and S3-12.3\%) or of highest quality, followed by good quality (G9.7\%) and the rest are residuals ( $\mathrm{O}$ and $\mathrm{T})$ thus commanding very good prices. The good post harvest/processing practices observed like immediate processing of tuxied abaca and immediate drying of extracted fibers under the sun or air-drying under the shade resulted in good quality fibers (Fig. 3).

On the third year from planting, it was observed that the abaca plants were taller and bigger than in the previous year. Among the varieties/hybrids, the Tangongon varieties produced significantly shorter stalks of about $3.3 \mathrm{~m}$ compared to the other three varieties which ranged from 3.6-4.1m (Table 3). There were no significant varietal differences in the weight of the stalk which ranged from $25.4 \mathrm{~kg}$ for Tangongon to $32.6 \mathrm{~kg}$ for Magino.

The fiber yield per plant of the various varieties was not statistically different but it was the number of plants harvested which significantly differed. Tangongon variety consistently produced the least number of harvestable plants with only 1.8 plants/clump which was significantly lower compared to the rest with comparable harvested stalks ranging from 2.9 - 3.1 plants/clump. The consistently good yield attributes of Magino hybrid i.e. longer and heavier stalks, good suckering ability and high fiber yield made it the highest yielder with 2.6 ton/ha of dry fiber. It was followed by Bongtang hybrid and Maguindanao variety with comparable yields of 2.1 and 2.0 ton/ha respectively. Magino hybrid was significantly superior over Tangongon variety which produced 1.2 ton/ha of fiber only. The poor suckering ability, low number of harvestable plants and shorter and lighter plants of Tangongon under coconut contributed to its low fiber production. Tangongon is one of the recommended varieties for Mindanao together with Maguindanao and Bongolanon, two of the parent materials of the hybrids (Anon, 1970) but under coconut, the variety performed poorly.

Due to lack of readily available and skilled labor to do the harvesting till fiber extraction, the fiber yield during the fourth year after planting was just estimated based on the current number of harvestable plants and the average fiber yield per plant obtained in the previous years. It was observed that Magino hybrid consistently produced the most number of harvestable plants per clump at 4.50 while Tangongon gave the least of only 2.25 plants/clump (Table 4 ). These produced an estimated fiber yield of 1.37 ton/ha and $2.68 \mathrm{ton} / \mathrm{ha}$, respectively. It is noteworthy that the yields obtained under coconut by the top three entries starting in year 2 which ranged from 2.0-2.6 ton/ha approximated the yield potentials of the crop which is 2 ton/ha and more than the annual average yields of $800 \mathrm{~kg} / \mathrm{ha}$ (Lalusin, 2010).

Aside from the agronomic performance of the varieties, the efficiency of utilizing the agricultural inputs applied to the crop specifically fertilizer expressed as Crop Fertilizer Use Efficiency (CFE) was analyzed. The CFE index used was CFEf which is the ratio of dry fiber yield ( $\mathrm{g}$ ) with fertilizer applied per plant 
Figure 2. Promising abaca variety/hybrids, Magino, Bongtang and Maguindanao, producing more suckers than Tangongon variety grown under 'LAGT'palms at PCA-DRC, 2007

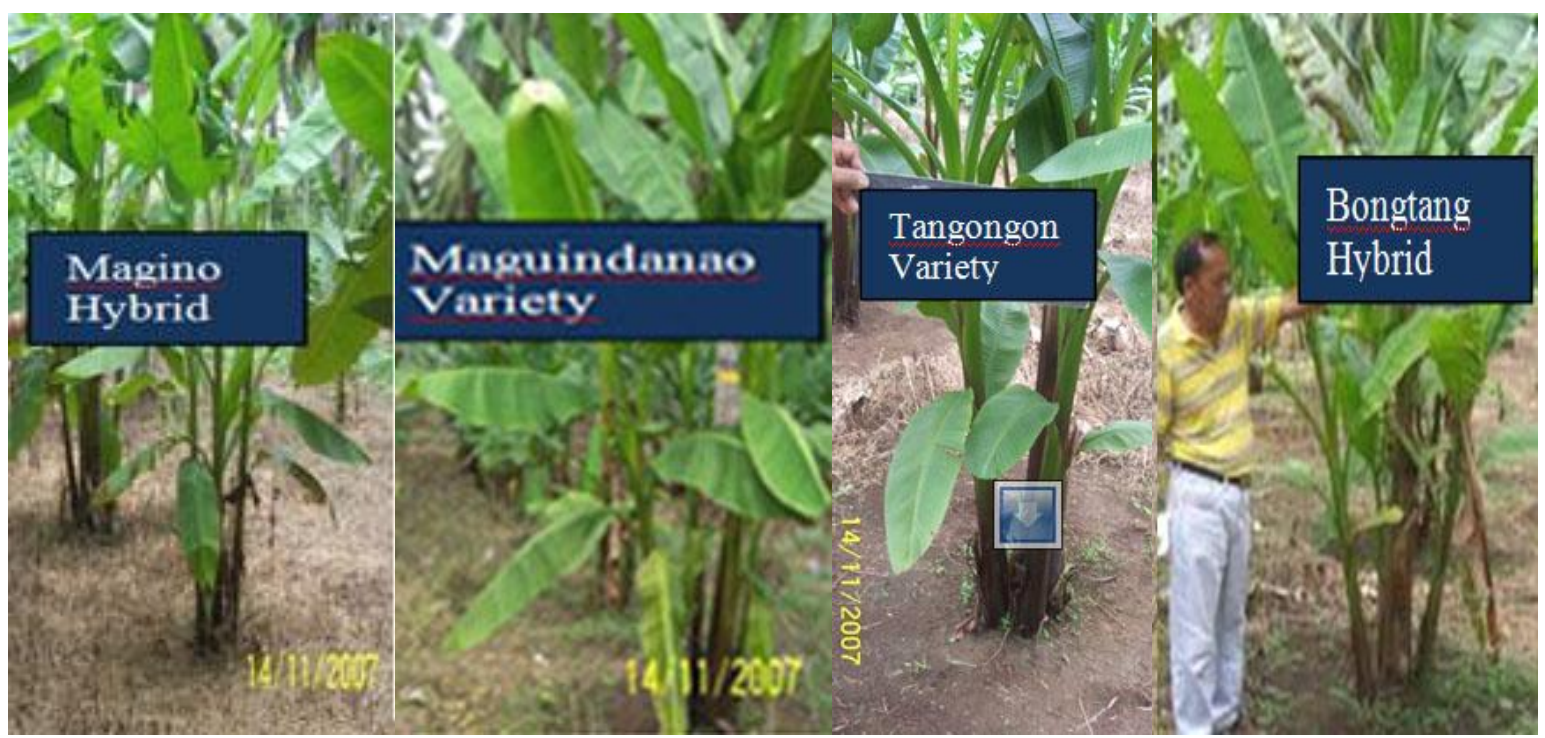

Table 2. Yield and yield attributes of four abaca varieties/hybrids under mature LAGT coconut at two years from planting (based on 1 harvest only, PCA-DRC, 2008)

\begin{tabular}{|c|c|c|c|c|c|}
\hline Entries/Varieties & $\begin{array}{l}\text { Length of } \\
\text { stalk (m) }\end{array}$ & $\begin{array}{c}\text { Weight } \\
\text { of stalk } \\
\text { (kg) }\end{array}$ & $\begin{array}{c}\text { No. of plants } \\
\text { harvested/ clump }\end{array}$ & $\begin{array}{c}\text { Dry fiber } \\
\text { yield/ } \\
\text { plant (g) }\end{array}$ & $\begin{array}{c}\text { Computed } \\
\text { Fiber Yield } \\
\text { (t/ha) }\end{array}$ \\
\hline T1-Tangongon var. & 2.77 & 19.9 & $2.4 \mathrm{~b}$ & $\begin{array}{c}505 \\
(2.5 \%)\end{array}$ & 0.5 \\
\hline T2-Maguindanao var. & 2.81 & 20.0 & $4.3 \mathrm{ab}$ & $\begin{array}{c}443 \\
(2.20 \%)\end{array}$ & 0.7 \\
\hline T3- Bongtang hybrid & 2.91 & 22.9 & $5.2 \mathrm{a}$ & $\begin{array}{c}453 \\
(1.98 \%)\end{array}$ & 1.0 \\
\hline T4- Magino hybrid & 2.93 & 18.8 & $4.0 \mathrm{ab}$ & $\begin{array}{c}390 \\
(2.07 \%)\end{array}$ & 0.6 \\
\hline F-test & ns & ns & $* *$ & ns & ns \\
\hline $\mathrm{CV}(\%)$ & 7.9 & 22.5 & 18.6 & 25.58 & 54.15 \\
\hline
\end{tabular}

Mean in the same column followed by a common letters are not significantly different at $5 \%$ level by DMRT. ns refers to non significant, * refers to significant, **efers to highly significant. 
Figure 3. Drying of abaca fiber immediately after fiber extraction to avoid deterioration of fiber quality (PCA-DRC, October 2009)

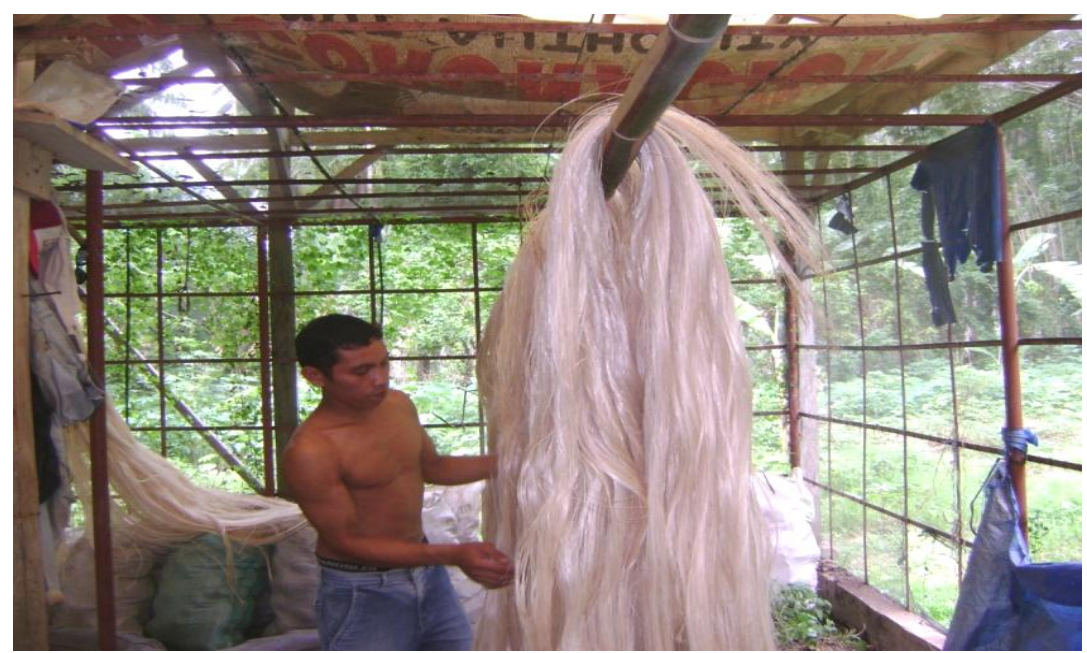

Table 3. Yield and yield attributes of four abaca varieties/hybrids planted under mature LAGT coconuts at three years from planting (based on 1 harvest only, PCA-DRC, October 2009)

\begin{tabular}{|l|c|c|c|c|c|}
\hline Entries/Varieties & $\begin{array}{c}\text { Length of } \\
\text { stalk (m) }\end{array}$ & $\begin{array}{c}\text { Weight of } \\
\text { stalk (kg) }\end{array}$ & $\begin{array}{c}\text { No. of plants } \\
\text { harvested/clump }\end{array}$ & $\begin{array}{c}\text { Dry fiber } \\
\text { yield/ plant } \\
(\mathbf{g})\end{array}$ & $\begin{array}{c}\text { Computed } \\
\text { Fiber Yield } \\
\text { (t/ha) }\end{array}$ \\
\hline T1-Tangongon var. & $3.3 \mathrm{~b}$ & 25.4 & $1.8 \mathrm{~b}$ & $\begin{array}{c}587 \\
(2.31 \%) \\
661\end{array}$ & $1.2 \mathrm{~b}$ \\
T2-Maguindanao var. & $3.6 \mathrm{a}$ & 30.2 & $2.9 \mathrm{a}$ & $\begin{array}{c}(2.19 \%) \\
633\end{array}$ & $2.0 \mathrm{ab}$ \\
T3-Bongtang hybrid & $3.7 \mathrm{a}$ & 31.1 & $3.1 \mathrm{a}$ & $\begin{array}{c}2.03 \%) \\
680\end{array}$ & $2.6 \mathrm{a}$ \\
T4-Magino hybrid & $4.1 \mathrm{a}$ & 32.6 & $3.6 \mathrm{a}$ & $(2.09 \%)$ & $*$ \\
\hline F-test & $* *$ & $\mathrm{~ns}$ & $*$ & $\mathrm{~ns}$ & $*$ \\
\hline CV $(\%)$ & 6.6 & 14.99 & 24.46 & 14.24 & 28.49 \\
\hline
\end{tabular}

Mean in the same column followed by a common letters are not significantly different at $5 \%$ level by DMRT. ns refers to non significant, * refers to significant, **refers to highly significant.

Table 4. Estimated fiber yield of four abaca varieties/hybrids planted under mature LAGT coconuts at four years from planting (PCA-DRC, October 2010)

\begin{tabular}{|l|c|c|}
\hline Entries/Varieties & No. of harvestable plants/clump & Estimated Fiber Yield (t/ha) \\
\hline T1-Tangongon var. & 2.25 & 1.37 \\
T2-Maguindanao var. & 3.62 & 2.22 \\
T3-Bongtang hybrid & 3.88 & 2.34 \\
T4-Magino hybrid & 4.50 & 2.68 \\
\hline
\end{tabular}


(g). It was shown that the top three high yielding entries (Magino, Maguindanao and Bongtang) had high CFEfs (7.66-8.44) compared to the poor performing variety, Tangongon, with only 4.51 (Table 5) implying that the former were more efficient in converting applied inputs into economic yield than the latter. Relatively Tangongon plant received higher amount of fertilizer due to few plants per clump to share/compete for the applied input yet its fiber yield is still comparable with the other entries.

The CFE analysis using fiber yield of abaca seemed to be a useful parameter in screening/selection of better varieties or planting materials. In coconuts, the CFE analysis, either as nut or copra-based, strongly appears to be a practical tool in identifying suitable/superior coconut varieties grown in different agroclimatic conditions (Magat, 1996). On corn inbreds (OPVs) and hybrids, the efficiency of phosphorus utilization in relation to yield under field conditions was reported to be a useful index in screening varieties (Fox, 1987).

\section{B. Economic performance of abaca under coconut}

The profitability of growing abaca as an intercrop was greatly influenced by the variety planted. Although, the investment yielded positive returns after the four years period making abaca farming under coconut an economically viable option in fully maximizing the vacant spaces under coconut, the magnitude of increase differed with the variety used (Table $6)$. The Tangongon variety had the least Benefit Cost Ratio (BCR) of 0.14 and the least Net Present Value (NPV) of only PhP16,976.96. The significantly inferior performance of the variety in terms of yield compared to the three others affected its financial returns. Magino and Bongtang hybrids had BCR of 0.43 and 0.41 and NPV at $12 \%$ interest at PhP78,458.45 and

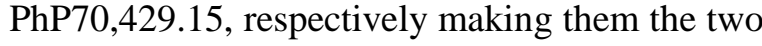
top earners.

\section{Influence of abaca on coconut productivity}

The yield of coconut was not significantly influenced by the variety of abaca planted (Table 7). The yields of coconut planted with abaca ranged from 50.1 to 62.1 nuts per tree, in which the copra yields are 322.4-346.5 g per nut and 16.33-21.25 kg copra per tree. However, abaca intercropping had yield-enhancing effect on the main crop. The yield levels of intercropped coconut were relatively higher than the adjacent mono cropped palms whose annual yields were only 47.35 nuts per tree or $15 \mathrm{~kg}$ copra per tree. Nut yield was increased by $20.17 \%$ and copra yield was increased by $26.0 \%$ implying positive improvement with abaca intercropping. Both cropping systems received same cultural management. Abaca does not compete with coconut for soil resources like its relative, the banana which is a popular intercrop, except probably in the dry zones (Magat, 2008).

One drawback encountered with abaca farming in Bago Oshiro, Davao City was the lack of readily available and skilled labor to do the harvesting till fiber extraction and primary processing. One best practice that should be strictly observed during fiber processing was to dry immediately the fiber to avoid discoloration and ensuring good quality of fibers. Poor quality fiber led to lower classification and hence very low prices.

\section{Conclusions and Recommendations}

Results revealed that comparable high fiber yields were obtained from the hybrids: Magino, Bongtang and the Maguindanao variety which were superior over the consistent lowest yielder, Tangongon variety. Growing them under coconut was very profitable as indicated by higher Net Present Values and Benefit Cost Ratios than the latter. Moreover, these superior varieties/hybrids were more efficient in converting inputs i.e. fertilizer, into economic yields as shown by their high crop fertilizer use efficiencies. Abaca growing had yield-enhancing effects on coconut especially in improving the nut and copra production of the palms. Likewise, abaca could be established sans other shade trees as the main crop already served the purpose. These clearly indicate that coconut area is a suitable expansion site for abaca farming and the crop mixed is highly profitable if the appropriate variety is used. 
Table 5. Crop Fertilizer Use Efficiency (CFE) of abaca varieties grown under coconut

\begin{tabular}{|l|c|c|c|}
\hline \multicolumn{1}{|c|}{ Entries/Varieties } & $\begin{array}{c}\text { Dry Fiber Yield } \\
\text { (g/plant, ave.2 years) }\end{array}$ & $\begin{array}{c}\text { Amount of fertilizer } \\
\text { applied/plant annually } \\
\text { (g, ave. 2 years) }\end{array}$ & CFE \\
\hline T1-Tangongon var. & 546 & 121.0 & 4.51 \\
T2-Maguindanao var. & 552 & 72.1 & 7.66 \\
T3-Bongtang hybrid & 543 & 64.3 & 8.44 \\
T4-Magino hybrid & 535 & 65.9 & 8.11 \\
\hline
\end{tabular}

${ }^{1}$ Average yield obtained at $2^{\text {nd }}$ and $3^{\text {rd }}$ year after planting

${ }^{2}$ Average amount of fertilizer received per plant during the $2^{\text {nd }}$ and $3^{\text {rd }}$ year derived by dividing the total fertilizer applied per clump with the number of plants/clump

Table 6. Comparative economic performance of the various abaca varieties/hybrids under mature tall coconut (per ha basis, 4 year period, PCA-DRC, Davao City)

\begin{tabular}{|l|c|c|c|c|c|}
\hline \multicolumn{1}{|c|}{ Indicator $(\mathbf{P h P})^{*}$} & Tangongon & Maguindanao & Bongtang & Magino & Average \\
\hline Total Costs & $160,506.18$ & $220,256.66$ & $237,038.33$ & $251,017.69$ & $217,204.72$ \\
Total Income & $197,450.37$ & $316,951.32$ & $350,514.66$ & $378,473.38$ & $310,847.43$ \\
Net Income/Loss & $36,944.18$ & $96,694.66$ & $113,476.33$ & $127,455.69$ & $93,642.72$ \\
Net Present Value (12\%) & $16,976.96$ & $57,956.16$ & $70,429.15$ & $78,458.45$ & $55,955.18$ \\
Benefit Cost Ratio & 0.14 & 0.36 & 0.41 & 0.43 & 0.34 \\
\hline
\end{tabular}

*PhP - Philippine Peso

Table 7. Annual yield of coconut as influenced by abaca intercropping (PCA-DRC, 2010)

\begin{tabular}{|l|c|c|c|}
\hline \multicolumn{1}{|c|}{ Treatment } & Nut/Tree (no.) & Copra/nut (g) & Copra/tree (kg) \\
\hline Tangongon & 58.3 & 339.0 & 19.84 \\
Maguindanao & 62.1 & 346.5 & 21.25 \\
Bongtang & 55.8 & 322.4 & 17.86 \\
Magino & 50.1 & 335.4 & 16.33 \\
\hline Stat. significance & $\mathrm{ns}$ & $\mathrm{ns}$ & $\mathrm{ns}$ \\
CV (\%) & 27.9 & 7.60 & 26.10 \\
\hline Coconut plant with abaca intercrop & 56.9 & 335.7 & 18.9 \\
Coconut plant without abaca monocrop & 47.35 & 317.6 & 15.0 \\
\hline \% yield increase with abaca & 20.17 & 5.7 & 26.0 \\
\hline
\end{tabular}


Some best practices to be observed by farmers to ensure good quality fibers and better classification that command very good prices are: a.) immediate stripping of tuxies either by hand or mechanical stripper within the day it was removed from the stalk b.) immediate and complete drying of stripped abaca fibers either through sun drying or air drying under the shade and not touching soil or any foreign materials to avoid fiber discoloration and c.) drying and storing fibers in areas free from foreign matters i.e. twigs, leaves. Nevertheless, readily available skilled labor in abaca processing in the locality is crucial in abaca farming.

\section{Acknowledgement}

The authors wish to express their gratitude to the field staff of the Agronomy and Soil Division of PCA-DRC led by the newly-retired field supervisor, Mr. Edilberto G. Cuison, for the efficient establishment, maintenance of the crop and assistance in data collection. Appreciation is also extended to the former Dept. Manager of PCA-DRC and now the APCC Executive Director, Mr. Romulo N. Arancon for the idea of showcasing coconut+abaca farming, the first in the history of coconut research in the Center. Sincere thanks is extended to the following for the various support and assistance extended in the realization of this endeavor: the PCA-DRC headed by Mr. Lornito U. Orillaneda, OIC-Dept. Manager of DRC and administrative staff for providing the necessary financial and administrative support and the staff of Fiber Development Authority of Region XI for the various technical and some logistical support provided during the conduct of the study, to our families, for the understanding and moral support and to our God Almighty, for the guidance and wisdom to finish the work despite some odds.

\section{References}

Anon. 1970. Recommended abaca varieties. UPCA Monthly Bulletin. 35 (10):5 In Abstact Bibliography of Abaca. 1905-1975 by International Documentation Center on
Abaca University of the Philippines at Los Banos.90 pp.

FIDA. 2004. Adaptability of Selected Abaca (Musa textilis nee) Varieties Under Different Agro-climatic Condition in the Philippines. Paper presented during the International Dissemination Seminar of the CFC_UNIDO assisted project AbacaImprovement of Fiber Extraction and Identification of High Yielding Varieties held on October 19, 2004 at Renaissance New World Hotel, Makati City, Philippines.

FIDA. 2005. Farmers' Manual On Abaca Production. CFC-UNIDO-FAO. 99p.

FIDA. 2007. Buying prices of Abaca and Ramie Fibers Per Kilogram and Per Grade. May 2007. FIDA Region XI. 1p

FIDA. 2012. Abaca. 2 August 2012. $<$ http://fida.da.gov.ph/Templates/abaca_hi story.htm>.

Fox, R.H. (1978). Selection for Phosphorus Efficiency. Communications in Soil Science and Plant Analysis 9:13-37

Lalusin, A. 2010. Abaca Breeding for a More Reliable Philippine Abaca Industry. Annual BSP-UP Professorial Chair Lectures. 15 - 17 February 2010. Bangko Sentral ng Pilipinas Malate, Manila

Magat, S.S. 1996. Crop Fertilizer Use Efficiency Analysis (CFE): A tool in identifying appropriate planting materials of coconuts in different agro-climatic conditions. Cord 12(2)

Magat, S.S. 2008. Enhancement of Economic Benefit from Selected Coconut-based Farming Systems (CBFS) Practice and Technologies. The Philippine Journal of Coconut Studies. 32(1): 12-23.

Tafalla, P.B.1991. Performance Test of Promising Abaca Cultivars Planted Under Coconut Plantation. Fiber Industry Research Bulletin. FIDA. 4p. 